\title{
PENGELOLAAN DANA KELURAHAN DALAM PERSPEKTIF COMMUNITY DRIVEN DEVELOPMENT
}

\author{
*Mashuri ${ }^{1)}$, Suwarno $^{2)}$, Teguh Pramono ${ }^{3)}$ \\ 1) Program Studi Administrasi Publik Universitas Kadiri, Indonesia \\ 2) Program Studi Administrasi Publik Universitas Kadiri, Indonesia \\ 3) Program Studi Administrasi Publik Universitas Kadiri, Indonesia \\ *Email Korespondensi : mashuri@unik-kediri.ac.id
}

\begin{abstract}
Abstrak
Sebagai bagian dari perangkat kecamatan dengan fungsi pelaksana pelayanan masyarakat, kelurahan mendapatkan dukungan anggaran tambahan dari pemerintah yang disebut sebagai dana kelurahan. Pengelolaan dana kelurahan di Kelurahan Kauman, Kabupaten Tulungagung dilakukan melalui kolaborasi antara kelurahan dengan masyarakat. Masyarakat diwakili oleh kehadiran Lembaga Pemberdayaan Masyarakat Kelurahan (LPMK). Penelitian ini berfokus untuk mendeskripsikan dan menganalisis pengelolaan dana kelurahan oleh LMP Kelurahan Kauman dalam perspektif Community Driven Development (CDD). Hasilnya, secara garis besar pengelolaan dana kelurahan oleh LPM Kelurahan Kauman telah menunjukkan lima karakteristik utama konsep $C D D$, yaitu: (1) Fokus pada masyarakat; (2) Perencanaan dan perancangan partisipatif; (3) Kontrol Masyarakat atas sumberdaya; (4) Pelibatan masyarakat dalam pelaksanaan serta (5) Monitoring dan evaluasi berbasis masyarakat.
\end{abstract}

Kata Kunci: Pembangunan Berbasis Komunitas; Dana Desa; Pelayanan Masyarakat

\begin{abstract}
As part of the sub-district apparatus with the function of implementing community services, the kelurahan receives additional budgetary support from the government, called the kelurahan fund. Village fund management in Kauman Village, Tulungagung Regency is carried out through collaboration between the kelurahan and the community. The community is represented by the presence of the Village Community Empowerment Institute (LPMK). This study focuses on describing and analyzing the management of kelurahan funds by the Kauman Kelurahan LMP in the perspective of Community Driven Development (CDD). The result, in general, the management of kelurahan funds by LPM Kauman Village has shown five main characteristics of the CDD concept, namely: (1) Focus on the community; (2) Participatory planning and design; (3) Community Control over resources; (4) Community involvement in implementation and (5) Community-based monitoring and evaluation.
\end{abstract}

Keywords: Community Driven Development; Village Funds; Public Service 


\section{PENDAHULUAN}

Di masa pemerintahan Presiden Joko Widodo, kelurahan mendapatkan perhatian lebih daripada sebelumnya. Sebagai bagian dari perangkat kecamatan dengan fungsi pelaksana pelayanan masyarakat, kelurahan mendapatkan dukungan anggaran tambahan dari pemerintah yang disebut sebagai dana kelurahan. Permendagri Nomor 130 Tahun 2018 Tentang Kegiatan Pembangunan Sarana dan Prasarana Kelurahan dan Pemberdayaan Masyarakat di Kelurahan, menyebutkan bahwa dana kelurahan bersumber dari Dana Alokasi Umum Tambahan (DAU Tambahan). Dana kelurahan dapat dimanfaatkan baik untuk pembangunan fisik maupun non fisik. Pembangunan fisik, mencakup pembangunan sarana dan prasarana di wilayah kelurahan. Sementara pembangunan non fisik, dapat berupa kegiatan pemberdayaan masyarakat di kelurahan. Sebagaimana Aida dan Zahara (2018:3) menyatakan bahwa, "Rencana dari pemanfaatan dana kelurahan ini adalah untuk dana infrastruktur kelurahan, peningkatan kualitas hidup masyarakat kelurahan dan stimulasi perekonomian masyarakat”.

Tahap pertama pencairan dana kelurahan dilakukan pada bulan Mei 2019. Kabupaten Tulungagung merupakan salah satu kabupaten di Indonesia yang menerima alokasi dana kelurahan. Terdapat 14 wilayah kelurahan di Kabupaten Tulungagung. Masing-masing kelurahan mendapatkan alokasi dana kelurahan sebesar Rp. 720.000.000, yang bersumber dari APBN dan APBD Kabupaten Tulungagung. Dari keempat belas kelurahan yang mendapat alokasi dana kelurahan, Kelurahan Kauman merupakan salah satu kelurahan yang sudah memulai mengelola dana kelurahan.

Pengelolaan dana kelurahan di Kelurahan Kauman dilakukan melalui kolaborasi antara kelurahan dengan masyarakat. Masyarakat diwakili oleh kehadiran Lembaga Pemberdayaan Masyarakat Kelurahan (LPMK). Sebagaimana Pasal 9 Permendagri Nomor 5 Tahun 2007 Tentang Pedoman Penataan Lembaga Kemasyarakatan bahwa, "Lembaga Pemberdayaan Masyarakat Desa atau Kelurahan (LPMD/ LPMK) dalam melaksanakan tugas mempunyai fungsi penyusunan rencana, pelaksanaan, pelestarian dan pengembangan hasil-hasil pembangunan secara partisipatif'. Hal tersebut memperlihatkan bahwa LPMK merupakan representasi dari masyarakat yang memiliki fungsi dalam perencanaan pembangunan partisipatif di tingkat kelurahan. Artinya, LPMK 
sebagai unsur masyarakat ditempatkan sebagai subyek sekaligus obyek dalam pembangunan di wilayah kelurahan.

Penempatan masyarakat tidak hanya sebagai obyek, melainkan juga sebagai subyek pembangunan telah dipraktekkan sejak lama. World Bank mengajukan sebuah konsep yang disebut sebagai Community Driven Development (CDD). Konsep CDD merupakan pengembangan konsep Community Based Development (CBD). World Bank (2003) mendefinisikan $C D D$ sebagai, "Sebuah pendekatan yang memberikan kontrol atas perencanaan/ pengambilan keputusan dan pengelolaan sumberdaya untuk pembangunan di tingkat lokal kepada sekelompok masyarakat". CDD merupakan pendekatan pembangunan yang mengedepankan inisiatif masyarakat untuk memperbaiki kualitas hidupnya sendiri (Kilby, 2011). menyebutkan bahwa terdapat lima karakteristik sebagai kunci utama pendekatan $C D D$, yang terdiri dari: (1) Fokus pada masyarakat; (2) Perencanaan dan perancangan partisipatif; (3) Kontrol masyarakat atas sumberdaya; (4) Pelibatan masyarakat dalam pelaksanaan serta (5) Monitoring dan evaluasi berbasis masyarakat.

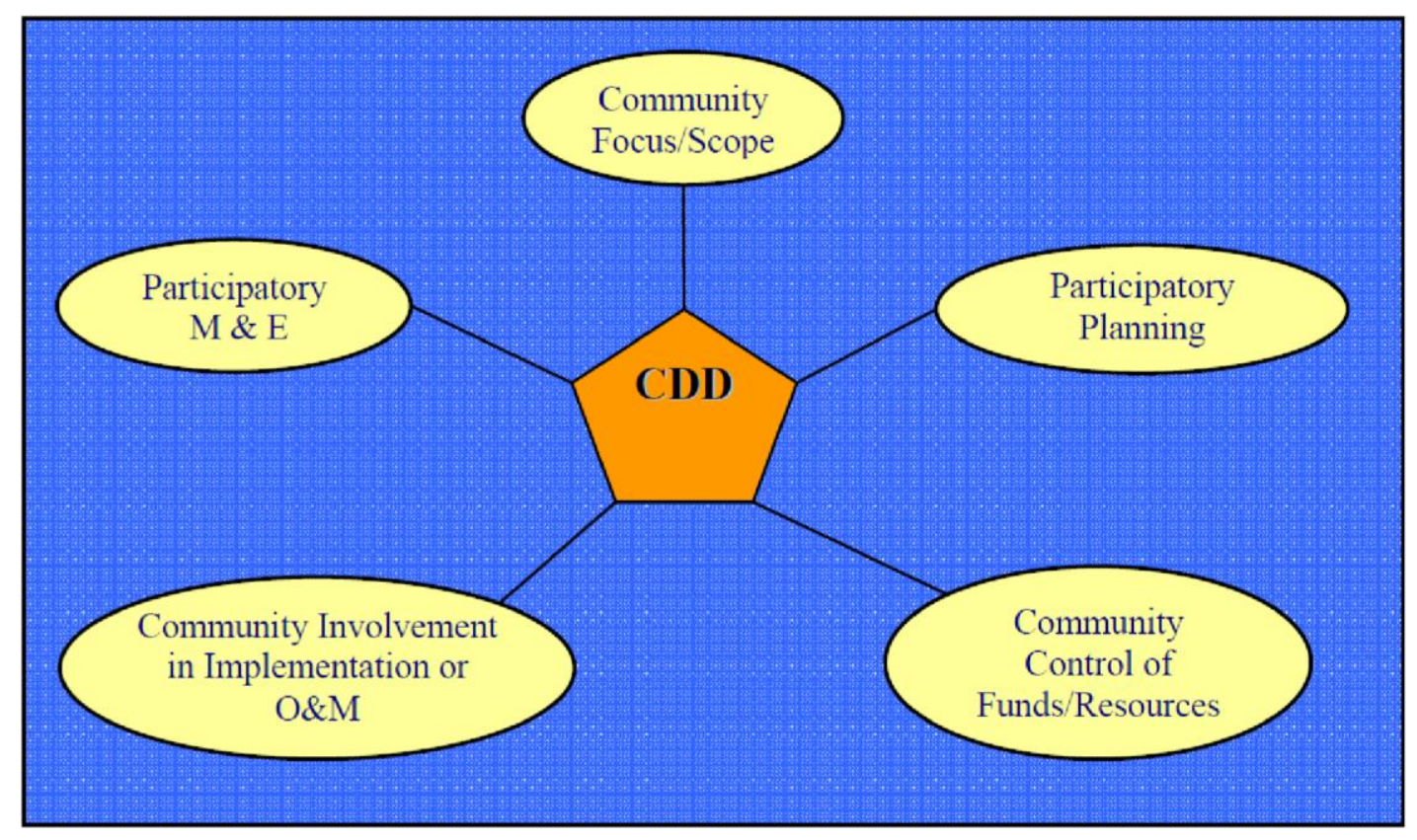

Gambar 1. Lima Karakteristik Utama CDD

Sumber: (Kilby, 2011) 
Terdapat beberapa penelitian yang meneliti pendekatan CDD. (Schuler \& Dwiyani, 2012) meneliti bagaimana pemerintah daerah di Nigeria dapat diberdayakan untuk berkontribusi bagi pengembangan mereka sendiri. Disimpulkan bahwa dukungan kapasitas, lembaga teknis dan lembaga non pemerintah adalah kunci untuk dukungan pemerintah daerah yang merupakan inti dari $C D D$. Selanjutnya, penelitian (Casey et al., 2011) menemukan efek jangka pendek yang positif pada penyediaan barang publik lokal, tetapi tidak ada dampak berkelanjutan pada penggalangan dana, proses pengambilan keputusan, atau keterlibatan kelompok terpinggirkan (seperti perempuan) dalam urusan lokal, menunjukkan bahwa $C D D$ tidak efektif dalam membentuk kembali institusi lokal yang tahan lama. Senada dengan Casey et.al, (Sitorus, 2017) menyatakan bahwa perubahan sosial yang diinginkan belum terlihat untuk masyarakat tradisional di Papua, yang sudah memperoleh program $C D D$ selama bertahun-tahun. Sementara (Labonne \& Chase, 2011), mengeksplorasi dampak modal sosial dari proyek CDD di Filipina pada masyarakat yang bersaing untuk mendapatkan block grant untuk pengelolaan infrastruktur. Hasilnya, ditemukan bahwa proyek dapat meningkatkan partisipasi dalam musyawarah desa dan frekuensi pejabat lokal bertemu dengan penduduk serta berdampak negatif pada aksi kolektif.

Kesamaan dari keempat penelitian di atas ialah dimana masing-masing penelitian tersebut melihat pendekatan $C D D$ pada wilayah rural atau perdesaan. Pendekatan $C D D$ pada dasarnya dapat digunakan secara luas baik pada masyarakat di wilayah perdesaan maupun masyarakat perkotaan atau urban. Hal tersebut ditegaskan oleh (Kilby, 2011) dimana pendekatan $C D D$ dapat digunakan dalam konteks: (1) Infrastruktur masyarakat desa/ kota - jalan desa, listrik desa, irigasi, sumber air, infrastruktur permukiman perkotaan, pendidikan kesehatan; (2) Pengelolaan sumberdaya milik bersama kehutanan, sumberdaya pesisir, sumber air; (3) Pembangunan usaha mikro/ koperasi; (4) Pemerintah daerah/ dukungan desentralisasi; dan (5) Pelayanan/ barang publik lain yang berskala kecil, tidak kompleks dan membutuhkan kerjasama lokal. Atas dasar hal tersebut maka penelitian ini berfokus untuk mendeskripsikan dan menganalisis pengelolaan dana kelurahan oleh LMP Kelurahan Kauman dalam perspektif Community Driven Development. 


\section{TINJAUAN PUSTAKA}

Menurut (Suwarno \& Bramantyo, 2019), melalui renungan, pemikiran, ide dan gagasan serta pengembangan ketrampilan sebagian masyarakat dalam suatu wilayah yang dapat mengelola wilayahnya menjadi lahan bisnis dan menghasilkan uang, membuat wilayah tersebut mengalami peningkatan kesejahteraan. Pengelolaan keuangan desa menurut (Hanum, 2018) meliputi perencanaan, pelaksanan, penatausahaan, pelaporan, pertanggungjawaban, pembinaan dan pengawasan serta responden dari masyarakat terkait.

Masyarakat memiliki peran untuk melakukan monitoring dan evaluasi berbasis masyarakat. Untuk itu diperlukan pengendalian mutu. Pengendalian kualitas menurut (Mujiarto et al., 2019) adalah keseluruhan cara yang digunakan untuk menentukan dan mencapai standar mutu. Atau dalam arti lain, pengendalian mutu adalah merencanakan dan melaksanakan cara yang paling ekonomis untuk dapat membuat sebuah produk yang akan bermanfaat dan memuaskan tuntutan dari konsumen secara maksimal.

\section{METODE PENELITIAN}

Penelitian ini menggunakan jenis penelitian deskriptif dengan pendekatan kualitatif. Alasan pemilihan jenis penelitian tersebut karena, peneliti meneliti sebuah fenomena pengelolaan dana kelurahan dalam perspektif Community Driven Development. Peneliti mengambil lokasi di Kabupaten Tulungagung. Dasar pertimbangan penetapan lokasi tersebut adalah karena Kabupaten Tulungagung menjadi salah satu daerah yang telah menerima dan mengelola alokasi dana kelurahan di Indonesia. Penelitian ini menggunakan tiga teknik pengumpulan data, yaitu: wawancara, observasi dan dokumentasi. Sementara, pada analisis data menggunakan analisis data kualitatif model interaktif dari Miles, Huberman (Saldana, 2014).

\section{HASIL DAN PEMBAHASAN}

Pengelolaan dana kelurahan dalam perspektif Community Driven Development $(C D D)$ dapat dideskripsikan dan dianalisis berdasarkan lima karakteristik utama yang diajukan oleh Kilby (2011) yaitu: (1) Fokus pada masyarakat; (2) Perencanaan dan 
perancangan partisipatif; (3) Kontrol masyarakat atas sumberdaya; (4) Pelibatan masyarakat dalam pelaksanaan serta (5) Monitoring dan evaluasi berbasis masyarakat.

\section{Fokus pada Masyarakat}

Pertama, fokus pada masyarakat. Pengelolaan dana kelurahan di Kelurahan Kauman didasarkan oleh Permendagri Nomor 130 Tahun 2018 Tentang Kegiatan Pembangunan Sarana dan Prasarana Kelurahan dan Pemberdayaan Masyarakat di Kelurahan. Disebutkan pada Pasal 14 bahwa, "Pelaksanaan anggaran untuk kegiatan pembangunan sarana dan prasarana lokal kelurahan dan pemberdayaan masyarakat di kelurahan melibatkan kelompok masyarakat dan/ atau organisasi kemasyarakatan”.

Hal tersebut sesuai dengan apa yang dikemukakan oleh Kilby (2011) bahwa, "Karakteristik penting yang menentukan dari operasi CDD adalah targetnya penerima manfaat/ penerima/ agen pelaksana adalah suatu bentuk organisasi berbasis masyarakat (Community Based Organization/ CBO) atau perwakilan pemerintah daerah dari suatu masyarakat". Tindak lanjut dari Permendagri Nomor 130 Tahun 2018 di atas adalah dikeluarkannya SK Lurah Kauman Nomor 04 Tahun 2019 Tentang Pengangkatan Kepengurusan Lembaga Pemberdayaan Masyarakat (LPM) Kelurahan Kauman. LPM Kelurahan Kauman merupakan bentuk dari Community Based Organization. Kepengurusan LPM Kelurahan Kauman beranggotakan tokoh masyarakat sebagai representasi dari masyarakat Kelurahan Kauman yang selanjutnya berperan mengelola dana kelurahan.

\section{Perencanaan dan Perancangan Partisipatif}

Kedua, perencanaan dan perancangan partisipatif. Setelah mendapat mandat resmi untuk mengelola dana kelurahan, sebagaimana ketetapan kedua SK Lurah Kauman Nomor 04 Tahun 2019 Tentang Pengangkatan Kepengurusan Lembaga Pemberdayaan Masyarakat (LPM) Kelurahan Kauman bahwa, "Tugas pokok LPM Kelurahan Kauman adalah sebagai mitra kerja Pemerintah Kelurahan dalam bidang perencanaan, pelaksanaan, pengendalian evaluasi dan tindak lanjut pembangunan yang bertumpu pada masyarakat". Hal tersebut sesuai dengan apa yang dikemukakan oleh Kilby (2011) bahwa, "Perancangan sub-proyek tingkat masyarakat dilakukan melalui perencanaan partisipatif 


\section{MEDIA505IAN}

Jurnal IImu Sosial dan IImu Administrasi Negara Vol.4 No.1 Tahun 2020

oleh masyarakat atau organisasi berbasis masyarakat itu sendiri; baru setelah itu dapat disebut didorong oleh masyarakat".

Perencanaan pengelolaan dana kelurahan dilakukan oleh LPM Kelurahan Kauman yang merupakan representasi dari RT, RW dan masyarakat Kelurahan Kauman bersama dengan Pemerintah Kelurahan Kauman. Tahap perencanaan dan perancangan partisipatif ini selanjutnya menghasilkan usulan rencana kegiatan pengelolaan dana kelurahan tahun anggaran 2019.

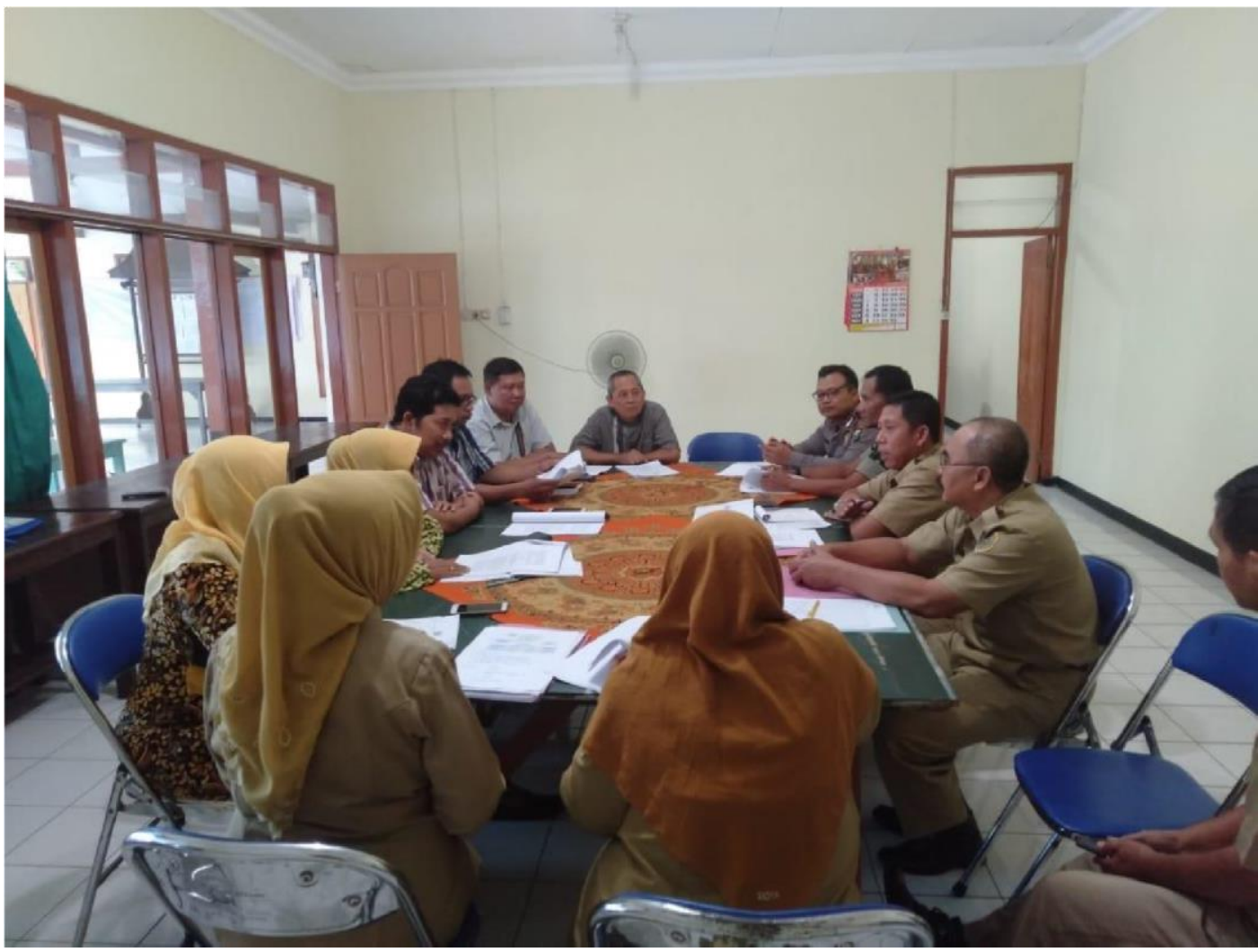

Gambar 2. Rapat Perencanaan Pengelolaan Dana Kelurahan oleh LPM Kelurahan Kauman bersama Pemerintah Kelurahan Kauman Sumber: Dokumentasi LPM Kelurahan Kauman

Terdapat 56 usulan rencana kegiatan yang terdiri dari 50 pembangunan fisik dan 6 pembangunan non fisik atau pemberdayaan masyarakat dengan total anggaran Rp. 720.000.000. Pembangunan fisik sebagian besar merupakan kegiatan revitalisasi bangunan. Mengingat letaknya yang berada di wilayah pusat kota Tulungagung, 
Kelurahan Kauman memiliki permasalahan yang sering dilanda daerah urban, salah satunya adalah daerah kumuh. Untuk itu LMP Kelurahan Kauman banyak mengusulkan kegiatan pembangunan fisik berupa pengecetan dinding pada gang, tepi jalan dan sepadan sungai. Sementara kegiatan non fisik atau pemberdayaan masyarakat berupa: pelatihan pembuatan souvenir, diklat toko online, diklat potong rambut, pelatihan karang taruna dan pembentukan forum anak kelurahan.

\section{Kontrol Masyarakat atas Sumberdaya}

Ketiga, kontrol masyarakat atas sumberdaya. Disebutkan dalam Ketetapan kedua SK Lurah Kauman Nomor 04 Tahun 2019 Tentang Pengangkatan Kepengurusan Lembaga Pemberdayaan Masyarakat (LPM) Kelurahan Kauman bahwa, "Dalam melaksanakan tugas pokok LPM Kelurahan Kauman mempunyai fungsi pengendalian dan pemanfaatan sumber daya kelembagaan untuk pembangunan di kelurahan". Dari ketetapan tersebut nampak bahwa LPM Kelurahan Kauman memiliki kewenangan atas sumberdaya yang dimiliki. Baik sumberdaya berupa anggaran yang berasal dari dana kelurahan maupun sumberdaya lain. Hal tersebut sesuai dengan apa yang dikemukakan oleh Kilby (2011) bahwa, "Setidaknya harus ada beberapa bentuk transfer sumberdaya ke masyarakat/ $C B O$, meskipun tingkat kontrol oleh masyarakat dapat bervariasi”. Kelurahan di Kabupaten Tulungagung mendapatkan anggaran dana kelurahan masing-masing sebesar Rp. 720.000.000. LPM Kelurahan Kauman memiliki kewenangan penuh untuk mengelola anggaran tersebut yang digunakan untuk pembangunan fisik dan pembangunan non fisik atau pemberdayaan masyarakat sebagaimana yang telah disusun dalam usulan rencana kegiatan pengelolaan dana kelurahan tahun anggaran 2019. Selain mengelola sumberdaya berupa anggaran, LPM Kelurahan Kauman juga menggunakan sumberdaya manusia yang merupakan warga Kelurahan Kauman dalam pelaksanaan kegiatan pembangunan fisik.

\section{Pelibatan Masyarakat dalam Pelaksanaan}

Keempat, pelibatan masyarakat dalam pelaksanaan. Keterlibatan LPM Kelurahan Kauman dalam pelaksanaan kegiatan pengelolaan dana kelurahan adalah dalam bentuk manajemen dan pengawasan kegiatan. Hal tersebut sesuai dengan apa yang dikemukakan oleh Kilby (2011) bahwa, "Keterlibatan ini sering berbentuk pasokan input, tenaga kerja 
atau dana secara langsung (sebagai bagian dari "kontribusi masyarakat" untuk subproyek), atau input tidak langsung melalui manajemen dan pengawasan kontraktor, atau operasi dan fungsi pemeliharaan (Operation and Maintenancel $O \& M$ )”. Manajemen kegiatan dilakukan melalui pembagian tugas pokok kepengurusan LPM Kelurahan Kauman yang terdiri dari ketua; sekretaris; bendahara; seksi ketentraman dan ketertiban masyarakat; seksi agama dan pemberdayaan perempuan; seksi pembangunan dan lingkungan hidup; seksi pemuda, olahraga dan seni budaya; seksi pendidikan dan keterampilan serta seksi kesehatan.

Tabel 1. Susunan Pengurus LPM Kelurahan Kauman Masa Bakti 2019-2024

\begin{tabular}{|c|l|l|l|}
\hline No. & \multicolumn{1}{|c|}{ Jabatan } & \multicolumn{1}{|c|}{ Nama } & \multicolumn{1}{|c|}{ Pekerjaan } \\
\hline 1. & Ketua & Drs. H. Mashuri, M.Si & Dosen \\
\hline 2. & Sekretaris & Ir. Iswahyuni Purwaningsih & Swasta \\
\hline 3. & Bendahara & Hasan, BA & Pensiunan \\
\hline 4. & $\begin{array}{l}\text { Seksi ketentraman dan } \\
\text { ketertiban masyarakat }\end{array}$ & M. Mahfud & Swasta \\
\hline 5. & $\begin{array}{l}\text { Seksi agama dan pemberdayaan } \\
\text { perempuan }\end{array}$ & Hj. Fatriyah & Wiraswasta \\
\hline 6. & $\begin{array}{l}\text { Seksi pembangunan dan } \\
\text { lingkungan hidup }\end{array}$ & Isdwi Priyanto, ST & Swasta \\
\hline 7. & $\begin{array}{l}\text { Seksi pemuda, olahraga dan } \\
\text { seni budaya }\end{array}$ & Agung Prayudi & Swasta \\
\hline 8. & $\begin{array}{l}\text { Seksi pendidikan dan } \\
\text { keterampilan }\end{array}$ & Dra. Ninik Mariyani & PNS \\
\hline 9. & Seksi kesehatan & Arina Salsabela, S.Pd & Swasta \\
\hline
\end{tabular}

Sumber: SK Lurah Kauman Nomor 04 Tahun 2019

\section{Monitoring dan Evaluasi Berbasis Masyarakat}

Kelima, monitoring dan evaluasi berbasis masyarakat. Kegiatan monitoring atau pengawasan dilakukan oleh LPM Kelurahan Kauman ketika kegiatan tengah berlangsung sampai kegiatan tersebut selesai. Monitoring dilakukan mulai dari tahap pengadaan barang, penggunaan material untuk pembangunan fisik yang berkualitas serta kesesuaian pelaksanaan kegiatan di lapangan dengan perencanaan yang telah disusun bersama sebelumnya. 


\section{MEDIA505IAN}

Jurnal IImu Sosial dan IImu Administrasi Negara Vol.4 No.1 Tahun 2020

Pengawasan juga dilakukan dengan membuka komunikasi dengan masyarakat sekitar tempat kegiatan berlangsung. Hal tersebut sesuai dengan apa yang dikemukakan oleh Kilby (2011) bahwa, "Kondisi ini tidak terlalu perlu sebagaimana semakin meningkatnya elemen umum dari desain proyek $C D D$. Alat akuntabilitas sosial, seperti pemantauan partisipatif, kartu skor masyarakat, atau sistem penanganan keluhan yang menjamin akuntabilitas ke bawah kepada masyarakat, merupakan bagian dari karakteristik ini”.

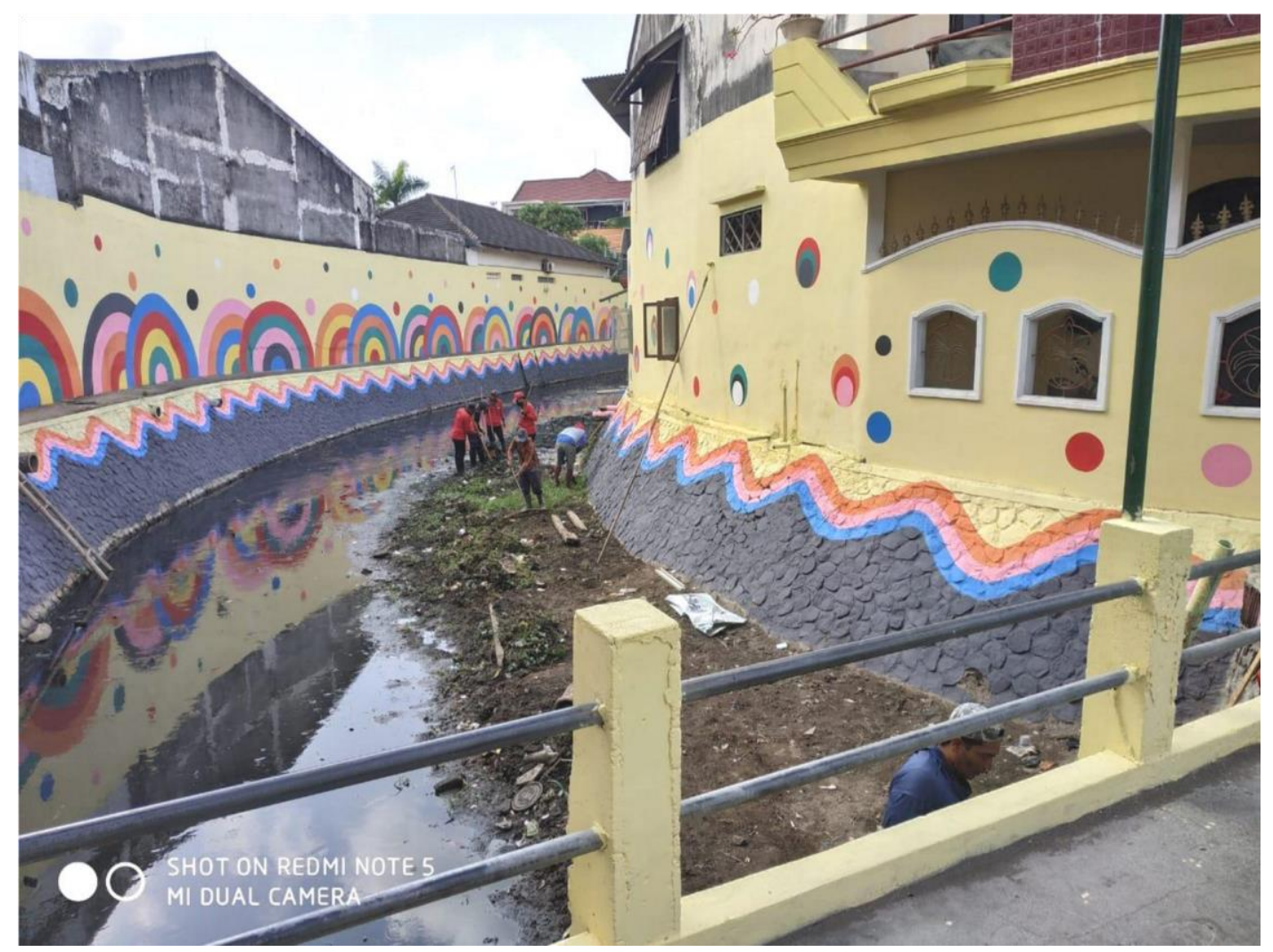

Gambar 3. Hasil Pengecetan Sepadan Sungai Jenis

Sumber: Dokumentasi LPM Kelurahan Kauman

Sementara untuk kegiatan evaluasi, dilakukan setelah berakhirnya kegiatan untuk tahun anggaran 2019. Evaluasi akhir pengelolaan dana kelurahan oleh LPM Kelurahan Kauman diselenggarakan di awal tahun 2020. Beberapa hal penting dibahas pada rapat evaluasi akhir tersebut guna meningkatkan efisiensi dan efektifitas pengelolaan dana kelurahan di masa yang akan datang. Tahap evaluasi menghasilkan beberapa point 
penting, antara lain: peningkatan intensitas komunikasi dan pemantauan di lokasi kegiatan sedang berlangsung, peningkatan kualitas dokumen perencanaan dan laporan, peningkatan sistem dokumentasi serta peningkatan penjaringan usulan masyarakat.

\section{KESIMPULAN DAN SARAN}

\section{Kesimpulan}

Sebagai mitra Kelurahan Kauman dalam mengelola dana kelurahan, LPM Kelurahan Kauman berperan mulai dari perencanaan sampai dengan evaluasi hasil pembangunan. LPM Kelurahan Kauman sebagai Community Based Organization secara garis besar telah menunjukkan pelaksanaan lima karakteristik utama konsep $C D D$, yaitu:

a. Fokus pada masyarakat;

b. Perencanaan dan perancangan partisipatif;

c. Kontrol Masyarakat atas sumberdaya;

d. Pelibatan masyarakat dalam pelaksanaan serta

e. Monitoring dan evaluasi berbasis masyarakat.

\section{Saran}

LPM Kelurahan Kauman diharapkan dapat meningkatkan proses perencanaan dan perancangan secara partisipatif. Melalui proses perencanaan dan perancangan secara partisipatif, diharapkan dapat menciptakan beragam usulan rencana kegiatan pembangunan non fisik atau pemberdayaan masyarakat. Sebab kehadiran dana kelurahan tidak hanya berfungsi sebagai dukungan pembangunan sarana dan prasarana kelurahan. Melainkan juga untuk mendukung kegiatan pemberdayaan masyarakat di kelurahan.

\section{REFERENSI}

Aida, Ade Nurul dan Zahara, Ervita Luluk. 2018. Dana Kelurahan dan Tantangannya. Jakarta:Pusat Kajian Anggaran Badan Keahlian DPR RI.

Casey, K., Glennerster, R., \& Miguel, E. 2011. Reshaping institutions: Evidence on external aid and local collective action. Citeseer.

Hanum, F. 2018. Akuntabilitas Keuangan Desa (Studi Kasus Desa Ngentrong Kecamatan Karangan Kabupaten Nganjuk). Jurnal Mediasosian: Jurnal Ilmu Sosial Dan Administrasi Negara, 2(1). 
Keputusan Lurah Kauman Nomor 04 Tahun 2019 Tentang Pengangkatan Kepengurusan Lembaga Pemberdayaan Masyarakat (LPM) Kelurahan Kauman.

Kilby, C. 2011. Informal influence in the Asian development bank. The Review of International Organizations, 6(3-4), 223.

Labonne, J., \& Chase, R. S. 2011. Do community-driven development projects enhance social capital? Evidence from the Philippines. Journal of Development Economics, 96(2), 348-358.

Mujiarto, M., Susanto, D., \& Bramantyo, R. Y. 2019. Strategi Pelayanan Kesehatan Untuk Kepuasan Pasien Di UPT Puskesmas Pandean Kecamatan Dongko Kabupaten Trenggalek. Jurnal Mediasosian: Jurnal Ilmu Sosial Dan Administrasi Negara, 3(1).

Peraturan Menteri Dalam Negeri Nomor 5 Tahun 2007 Tentang Pedoman Penataan Lembaga Kemasyarakatan.

Permendagri Nomor 130 Tahun 2018 Tentang Kegiatan Pembangunan Sarana dan Prasarana Kelurahan dan Pemberdayaan Masyarakat di Kelurahan.

Saldana. 2014. Qualitative Data Analysis, A Methods Sourcebook. UI-Press.

Schuler, N., \& Dwiyani, R. 2012. Rapid appraisal of PNPM neighborhood development (and poverty alleviation partnership grant mechanism).

Sitorus, Y. L. M. 2017. Community Driven Development In Traditional Communities In Papua. Journal of Regional and City Planning, 28(1), 16-31.

Suwarno, S., \& Bramantyo, R. Y. 2019. Pengaruh Gaya Kepemimpinan Terhadap Kinerja Organisasi. Transparansi Hukum, 2(1).

World Bank. 2003. World Bank Concept of the Poverty Alleviation Partnership Grant for Neighborhood Development. 